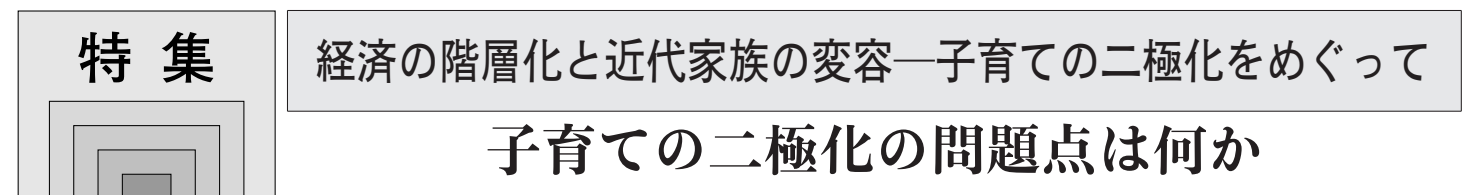

竹村祥子

要 約

1990 年代後半の経済の構造転換と家族の多様化により, 親の経済基盤の二極化が進んでいくなか, その状況の報告をうけて以下の点について検討する必要があると考えた。一つは, 首都圈の就学前児 童の保護者世帯の経済的差異や母親の学歴の差異と, 子どもの教育機会の差異が関連していることが どのような格差のあととなるかを考えること。二つめは, 「より良い子育て」や「リスク回避戦略」と して子どもに小・中学校受験をさせている親とそうでない親たちとの階層分断化, 生活圈での分断化 が起こる可能性があるということが首都圈特有の問題なのか，地方の家族においても潜在的に抱えて いる格差問題であるのかを精査していく必要があること。三つめは, 母子家庭の貧困・低所得問題之 母子家庭が幾重にも周縁化され，貧困の世代間再生産が起こっていることへの対処はどうすべきかを 考えることである。いずれにしてあ，このような家族の二極化によって，子どあの不平等（格差）が どのように進むのか，日本の家族全体の格差問題であるのかを検討し，対策を立てていくことが緊急 の課題である。

キーワード：家族格差, 家族変動, 地域格差

2009 , 家族社会学研究, 21(1): 57-60

What Are the Problems of Bipolarization in Parenting?

Sachiko Takemura

Abstract
The reports suggest that the polarization of households with children into rich and poor,
caused by changes in the economic fabric and by the diversifying of the norms and forms of the
family, intensified in the latter half of the 1990's. This gives rise to the following three
questions. First, it appears that, in metropolitan areas, children's chances for educational
promotion are correlated with the level of their household income and their mothers' educa-
tional background. What are the consequences of these correlations? Second, in metropolitan
areas, parents are divided into two groups in terms of their preferences in parenting. One
prefers that their children enter a private elementary and/or junior high school: they would like
to buy a better education for their children and avoid what they regard as a useless education
in a public school. The other prefers a more inexpensive public school to a private school. The
groups are divided not only into different strata, but also into different communities in the same
area. Is such a division also found in the countryside? Lastly, single-mother families are
isolated in current Japanese society and the issue of their poverty is sidelined, although it is a
major issue. Consequently, we consider the intergenerational reproduction of poverty in
single-mother families. How could we solve this problem? At the very least, reports signify that
it is a burning issue to investigate how the polarization of families promotes social inequalities
among children.

Key words: family differentials, family change, regional differences

2009, Japanese Journal of Family Sociology, 21(1): 57-60

たけむら さちこ：岩手大学

Iwate University, 3-18-34 Ueda, Morioka 020-8550, Japan 


\section{I. シンポジゥム趣旨の理解}

シンポジゥムは，まず司会の山田昌弘氏が，東 京 23 区の私 (国) 立小学校の進学状況別地図 (『東洋経済』2008.5.17) や23 区内で就学援助率 の高低で, 学力調査の平均点に差があるという資 料 (『ダイヤモンド』2008.8.30) などを提示して, 経済力のある家庭が多い地域は, 私 (国) 立小学 校へ進学している割合が高く, 子どあの学力屯高 いことの説明がなされた。その後, 三氏の報告が 始まった。

シンポジゥムの企画意図は, 以下のようにまと められている。戦後, 産業社会の発展ととあに, 近代家族の理念が普及し, 子どもの教育に熱心な 親が一般的になった。その結果, 高度成長期以降 1990 年頃までは, 親が安定した経済基盤をもつ ことにより，子どむへの教育投資は促進され，ど の子どあも親世代よりは学歴が上昇し, 世代間の 階層上昇があたりまえとなった。しかし，1990 年代後半の経済の構造転換と家族の多様化によ り, 親の経済基盤が二極化し, 子どもの早期教育 などハイパーな子育てに突き進む親を出現させる 一方で，子どものためにお金や時間を使いたくて む使えない親む出てきているという二極がみられ るようになる。このような状況の变化の中で, 子 育ての二極化がどのように進んでいるのか, 結果 として家族の階層化は進むのか, そして教育格差 は拡大するのか，その州結はどうなるのか，とい う点をめぐってシンポジウムが進行する予定で あった。その進行の中で討論者に期待された課題 は, 吉川徹氏には「階層と教育の関係の調査の視 点からの討論」, 竹村には「戦後家族の変化や地域 差に関する視点からの討論」ということであっ た。

\section{II. シンポジゥム報告の要点}

二極化した社会における子育て状況を解明する ことを目的として, 後藤憲子氏からは「子育て家 庭の世帯年収の減少と子育ての現状」が報告され
た。首都圈の就学前児童の保護者対象のベネッセ 調査のうちから, ’95 年, ’00 年, ’05 年調査が紹 介され，世帯年収や母親学歴の違いによって，子 どもにかける教育費用と選択される教育内容に違 いが出ているという結果が示された。報告結果の なかで注目しておきたいことは, 教育費の平均 は, ’00 年の時点で不況などの影響で一時減額す るものの, ’05 年になると, 世帯年収の多少にか かわらず，みな増加している。水泳などのスポー ツ系の習い事には，世帯年収による選択の差異が 見られないのに対して，英語については，800万 円以上の年収世帯では, 習わせる割合が上昇して いる。母親の学歴別にみると, 高卒の母親よりも 短大卒や大卒の母親のほうが，子どあに英語を習 わせる比率が伸びていることであった。この結果 から年収の高い世帯, 母親の学歴が高い世帯の早 期教育の志向の高まりを読み取ることができるの かもしれない。首都圏では, 世帯年収が平均以上 の世帯とそうでない世帯の経済的な二極化の様相 がはっきりしてきているだけではなく，母親学歴 の違いによって，子よ゙もに与えられる教育機会 (習い事)にも違いが出ていることが示された。と はいえこの調査は首都圈を中心とした調査の結果 であり，他の地域でも同じ傾向であるかどうかは わからない。またサンプルの年収の平均が高く, 200 万円未満のサンプルがほとんどおらず，首都 圏に限定した知見だとしても, 経済階層が非常に 低い世帯の動向はこの調査からは明らかにならな いだろう。また対象者が就学前の児童の保護者な ので, 中学校, 高等学校とさらに教育費がかさむ 時期の違いまでを示しているわけではないことに ついても注意する必要がある。

片岡栄美氏は,「格差社会と小・中学校受験一 受験を通じた社会的閉鎖，リスク回避，異質な他 者への寛容性」と題して以下のようなご報告をさ れている。関東圏の子育て期にある親を対象に 小・中学校受験についての意識を中心に社会関係 のあり方などを聞いている。この結果の中で注目 したいのは，高学歴家庭，高収入家庭ほど，小・ 
中学校受験率は高いこと, 専業主婦のいる家庭の 中学受験率は, 有職母親の家庭より高いことなど の差異がはっきり現れている点である。さらに早 期受験をさせる親（とくに母親）にとって受験を させることが，親たちのアイデンティティーをか けた子育ての競争であり,「同質性を背景とする 社会的閉鎖の戦略であり, リスク回避戦略」(シン ポジゥム資料）ともなっていることであった。受 験をさせたいと考えている親は, 「考え方や価值 観の合わない親とは付き合わない」の比率が高 く, 実際私立中学校に子どもを通わせている親 は, 「育児支援の担い手になる」,「地域活動の世話 や手伝いをする」，「町内会やPTA などの活動を する」割合が公立中学に通わせている親よりも低 い。「より良い子育て」の選択と希望成就の（た ぶん個々の家族の意困せ女) 結果として,「地域の 中では，お受験組とそうでない親たちとの階層分 断化, 生活圏での分断化」が進行しているのでは ないかと片岡氏は危惧する。

「授験組」の親たちは, 行き着くところ, 子ど むの将来像をめぐってどのような人生またはライ フスタイルを想定しているのか，気になるところ だ。私立小学校の選択肢が多くある大都市特有の 問題ではあるかむしれないが，親自身が，子ども を含めた自分たちの生活基盤となる社会とつきあ うことなく, 子ども自身も, 地域の人たちとかか わることの少ない生活を送り, 同質の同級生たち とともに小, 中, 高の学校生活を送り, その後ど のような社会のどのような階層に属する社会人と して, 生活を送ると考えているのだろうか。また, 生活基盤があるはずの地域社会の人たちと比較的 隔絶した生活がいつまで可能だと考えているの か, 気になるところだ。

湯澤直美氏は, 「母子世帯における『子どあの貧 困』と教育保障一子どあのライフチャンスと貧困 の世代的再生産」と題して報告された。母子世帯 の中にも階層性があることを前提に, ここでは 「ハードコア層としての中卒層」母親に着目し, 母 親本人の学歴取得の意味や「親の学歴階層の相違
が子どもの地位達成に与える影響」,「生活保護制 度の活用など社会資源へのアクセスが子よ゙ものラ イフチャンスにいかに機能するか」を明らかにし ている。中卒層の母親本人が, 貧困の当事者であ り, その貧困から脱出するためには学歴取得や資 格の取得が有効であることを知りつつも, 学歴や 資格取得・獲得汃ら疎外されていく状況や，最低 限の生活を維持するために, 現状の生活や家族の 安定を損なう選択をしてしまう仕組みが現実には あることが明らかにされていた。貧困状況にある 当事者の母親についてあ, 学歴取得の方策が採ら れるべきであることも提案されているが，貧困が 母子世帯の子どむに再生産されていくことをいか にして阻止していくかの方策として, 子どあの教 育のチャンスは, 家族の状況に従属することな く, 子どあ自身の教育機会均等を確保することが 大切であること，そのための政策は「教育を脱家 族化」していくべきであると提案されている。

\section{$\square$ III. 子育てをめぐる家族の二極化に 起因する困難一どのような困 難か，解決の方策はどうするか}

今回報告の三氏が共通して指摘されたことは, 世帯（家族）の経済格差と母親の学歴格差に起因 する子どもの教育からの疎外と不平等な状況につ いてであった。教育費を多く出せる保護者とそう でない保護者, 学歴が高く, 子どあの教育に時間 をかけられる母親とそうでない母親, という家族 の二極化は進んでいる。この二極化は, どのよう な家族に生まれるかによって，その子よ゙あの屯つ 教育資源は, はじめから極端に違い, 子どもに とっての教育機会が不平等になっているという問 題であり, 子育ての二極化に起因する困難と考え てよいのだろう。ただし，ここで指摘された不平 等問題は, 進路選択可能性が多様化している地域 でのみ成立する問題であり, 地方在住の家族に とってみれば，「自分たち家族」の問題ではない。 地方在住の家族の家族資源格差問題は, 地域内の 
小学校の廃校・統合問題であり, 特に過疎化する 地域では, 選択肢がない進学状況・教育環境問題 であること屯指摘しておきたい。

\section{二つめは,「より良い子育て」や「リスク回避戦} 略」として子どもに小・中学校受験をさせている 親とそうでない親たちとの階層分断化, 生活圈で の分断化が起きつつあり, 地域社会の分断につな がるかむしれないおそれが出てきていることであ る。これは, 首都圏特有の問題として局地化する ことのできない課題かもしれない。子育てを通し て地域社会とつながっていくことも子育ての戦略 としてあり得る選択なのに,「よりよい子育て」を 理由に地域社会と一線を引いてつきあうことは, 子どもへの期待として,「国籍の違う子どあと友 だちになる」ことを期待することとは矛盾しない のだろうか。地方在住の家族においても共同性と
対立する「よりよい子育て」志向があるのかは踏 査していく必要があるだろう。

三つめには, 母子世帯の貧困の再生産メカニズ ムは一般化できるか, という点である。大都市圈 以外の地域においても, 母子世帯の貧困状況は存 在し, 地方都市や農村部特有の困窮があるときい ている。今後有効な母子家族政策を具体化するた めに, 行政単位の地域差を明らかにすることは, 政策対応の「戦略」としても必要だろう。

その家族に生まれたために貧困を再生産し, 教 育機会から屯遠ざかってしまうことこそ問題で, 社会や経済格差が原因でありながら，個々の家族 の努力だけで乗り越えられるような錯覚をむたせ ている社会のありようは近代家族のあっている根 本問題である。 